\title{
БОРОТЬБА РАДЯНСЬКОЇ АДМІНІСТРАЦІЇ ПРОТИ УКРАЇНСЬКОГО ВИЗВОЛЬНОГО РУХУ У КАРПАТСЬКОМУ КРАЇ ОУН ЗАСОБАМИ КОЛЕКТИВІЗАЦІЇ
} $(1945-1952)^{*}$

\begin{abstract}
У статті розкривається одна із форм боротьби радянської репресивно-каральної системи проти українського визвольного руху у Карпатському краї ОУН (1945 - 1952). Розкриті заходи (пропагандистські та збройні) українських націоналістів супроти колективізаиії. Наведені приклади результативності иього напряму роботи націоналістів. Показано хід і масштаби колективізації селянства у карпатському регіоні. Встановлено, щу колективізачія, попри тиск, не відбувалася бажаними для влади темпами.
\end{abstract}

Ключові слова: колективізація, Карпатський край ОУН, репресивно-каральна система.

Jim. 36.

Vasyl ILNYTSKYI, Ph D hab. (History), Associate Professor, Head of Ukraine's History Department of Drohobych Ivan Franko State Pedagogical University (Ukraine,Drohobych)vilnickiy@gmail.com

\section{THE STRUGGLE OF THE SOVIET ADMINISTRATION AGAINST UKRAINIAN LIBERATION MOVEMENT IN KARPATSKYI KRAI OF THE OUN (1945 - 1952) BY MEANS OF COLLECTIVIZATION}

In the article one of the forms of the Soviet repressive system's struggle against Ukrainian liberation movement in the Carpathian area of the OUN (1945 - 1952) is revealed. As many of Ukrainian archives were closed until recently, it did not allow researchers in a complex way to disclose the scales of this phenomenon. The questions concerning forms and methods of carrying out of the collectivisation have been elucidated in generalising works on the history of Ukrainian peasantry and Ukrainian liberation movement. Notwithstanding that, there is yet no separate research which would clarify the features of the collectivisation in the Carpathian area of the OUN, which covered the former Drohobych, Transcarpathian, Stanislaviv and Chernivtsi regions of Ukraine.

For the liberation movement peasantry was a social and economic base, a source of replenishment of human resources and of alternative information. It is expedient to underline, that the collectivisation essentially undermined the social and material resources of Ukrainian liberation movement. That is why a priority task that the nationalists were facing then was to find a source of collection of foodstuff and industrial goods. Thus, it is necessary to specify that the Soviet power tried to split the Ukrainian society by means of collectivisation, but, eventually, it did not succeed in doing that. For this reason, the Soviet management paid a special attention to the struggle against those who supported the underground and-at the same time-opposed the creation of collective farms. Accordingly, the Ukrainian nationalists struggled to support peasantry and helped it to bear the pressure of the Soviet administration. The article elucidates the Ukrainian nationalists' propaganda and military actions against collectivisation. The examples of productivity of this direction of the nationalists' work are demonstrated. The process and scale of collectivisation of peasantry in the Karpatskyi Krai are also shown. It is established that collectivisation, despite its strong pressure, did not take place at a desirable for the power rate.

Hence, the Soviet administration considered collectivisation as one of means of its struggle against the OUN and UPA. After all, it was because of the compulsory entry of peasants into collective farms that the nationalists were loosing their economic base and human resource. However, the liberation movement activity hampered the fast collectivisation of the village which became a success only as late as in the early fifties.

Key words: collectivisation, the Carpathian area of the OUN (alias Karpatskyi Krai), repressive-retaliatory system.

Ref. 36.

\footnotetext{
* Публікація містить результати досліджень, проведених при грантовій підтримці Держаного фонду фундаментальних досліджень за конкурсним проектом договір Ф77/80-2017 від 31.08.2017 р.
} 
Василий ИЛЬНИЦКИЙ,

доктор исторических наук, дочент, и.о. заведующего кафедры истории Украинь

Дрогобычского государственного педагогического университета имени Ивана Франко (Украина, Дрогобич)vilnickiy@gmail.com

\section{БОРЬБА СОВЕТСКОЙ АДМИНИСТРАЦИИ ПРОТИВ УКРАИНСКОГО ОСВОБОДИТЕЛЬНОГО ДВИЖЕНИЯ В КАРПАТСКОМ КРАЕ ОУН СРЕДСТВАМИ КОЛЛЕКТИВИЗАЦИИ (1945 - 1952)}

В статье раскрывается одна из форм борьбы советской репрессивно-карательной системы против украинского освободительного движения в Карпатском крае ОУН (1945 - 1952). Раскрыты мероприятия (пропагандистские и вооруженные) украинских начионалистов против коллективизации. Приведеные примеры результативности этого направления работы националистов. Показано ход и масштабы коллективизации крестьянства в карпатском регионе. Установлено, что коллективизация, несмотря на давление, не происходила желанными для власти темпами.

Ключевые слова: коллективизация, Карпатский край ОУН, репрессивно-карательная система.

Лum. 36.

Постановка проблеми. У боротьбі з підпіллям радянська система використовувала різноманітні форми й методи, більшість із яких не тільки суперечили міжнародним конвенціям, але й універсальним принципам загальнолюдської моралі. Одним із засобів, які використовувала репресивно-каральна система у боротьбі проти українського визвольного руху, була колективізація. Закритість українських архівів досі не дозволяла комплексно висвітлити масштаби цього явища. Тому аналогічні дослідження мають не лише наукове, але й суспільно-політичне значення.

Аналіз досліджень. Питання форм і методів проведення колективізації знайшли своє відображення в узагальнювальних працях з історії українського селянства [25] та українського визвольного руху $[26 ; 27 ; 31]$. Крім цього, за часи незалежності України з'явилися розвідки О. Мороза та С. Злупка [30], О. Ленартовича [28], М. Сеньківа [32; 33; 34] та ін., присвячені проблемам колективізації. Проте окремого дослідження, яке б розкривало особливості колективізації у Карпатському краї ОУН, що охоплював колишні Дрогобицьку, Закарпатську, Станіславську, Чернівецьку області УРСР, нема.

Мета статті - розкрити одну із форм боротьби радянської репресивно-каральної системи проти українського визвольного руху у Карпатському краї ОУН (1945 - 1952).

Виклад основного матеріалу. Соціально-економічною базою, джерелами поповнення людських ресурсів та альтернативної інформації для визвольного руху було селянство. Саме тому радянське керівництво особливу увагу приділяло боротьбі з тими, хто підтримував підпілля й водночас противився створенню колгоспів. Йдеться тут передовсім про одноосібні селянські господарства. Відповідно українські націоналісти боролися за підтримку селян і допомагали їм витримувати натиск радянської адміністрації. У листі провідника Карпатського крайового проводу ОУН Я. Мельника-«Роберта» до керівника Станиславівського окружного проводу Михайла Хмеля (Хміля)-«Всеволода» (26 грудня 1945 р.) зазначалося: «Із числа більшовицької адміністрації ми допускаєм існування сільрад і голів сільрад, разом із тим необхідно знищувати обов'язково клуби (підкреслено двічі), як вогонь більшовицької пропаганди, земельні общини (підкреслено двічі), як зародок колгоспів і жіночі ради, які $є$ спробою окупанта завоювати собі депровіційний вплив на сім'ї і т.д.» [35, 6-8]. У питаннях колективізації рекомендувалося а) підтримувати супротив тих селян, які ще не вступили в колгоспи; б) намагатися мати вплив на адміністрацію (своїх людей) у створених колгоспах; в) затримувати вивіз хліба; г) уникати будівництва в колгоспах суспільного сектору (конюшні, сараї і т.д.); г) добиватися збільшення оплати трудодня; д) колгоспну адміністрацію, яка відверто співпрацювала з окупантами, спочатку попереджувати, застосовувати фізичні покарання, а переконаних вбивати; е) не знищувати колгоспного майна, за винятком такого, яке слугувало для грабунку. Паралельно населенню рекомендувалося - не відкритими листівками, а конспіративно, - передовсім засіяти всі поля, значну частину зерна сховати, здавати повільно, систематично що-небудь недодавати. При плановому господарстві це призводило до 
зриву плану i, безумовно, серйозно впливало на економіку країни. Надавалася підтримка селянам-одноосібникам стосовно перешкоджання передачі їхнього майна в розпорядження колгоспів. Проти колективізації діяли пропагандою як серед населення, так і серед членів ініціативних груп. Якщо колгосп уже був організований і охоплював усе село, то заборонялося знищувати колгоспне майно, оскільки тоді населення могло виступити проти повстанців. Отже, колгосп дозволялося розігнати на початку, коли до нього були залучені ще небагато осіб [2, 125-126]. Таким чином, наприкінці 1940-х рр. позиція ОУН щодо колгоспів полягала у захисті інтересів колгоспників та у повній ліквідації колгоспної системи. При цьому підпільники звертали особливу увагу на те, щоб тримати колгоспну адміністрацію під впливом і була можливість саботувати й зривати колгоспне будівництво тощо $[16,295 ; 6,32,88]$.

На нараді керівників ОУН у липні 1948 р. в Ілівському лісі (Миколаївський район) особливу увагу було надано питанням боротьби проти колективізації. Її результатом було прийняття відповідного рішення. Націоналісти розглядали колективізацію західних областей УРСР на рівні осібно вагомої проблеми. Вони розуміли, що якщо радянській владі вдасться ії завершити, то це завдасть підпіллю важкого удару і поставить його на межу знищення. У світлі цього було дано чіткі вказівки вести жорстку боротьбу із колективізацією. Пропонувалося знищувати активістів і організаторів колгоспів, колгоспні будівлі та інші матеріальні цінності, техніку й інвентар примушувати адміністрацію і колгоспників саботувати виконання вказівок роботи у колгоспах $[15,2,32]$.

Доцільно наголосити: колективізація суттєво підривала соціальну та матеріальну базу українського визвольного руху. У зв’язку з цим перед націоналістами стояло першочергове завдання шукати джерела заготівлі продуктів харчування й промтоварів, зокрема, шляхом грабування магазинів сільпо і тваринних ферм, а також розкрадання майна колгоспів за допомогою введених туди симпатиків $[11,342]$. При цьому зазначимо, що радянська влада намагалася розколоти суспільство колективізацією, чого, однак, їй зробити не вдалося.

У боротьбі проти колективізації українські націоналісти широко використовували спеціальні заклики: «Увесь світ розпочав сьогодні боротьбу проти большевицької зарази України, українському народові большевицький імперіалізм загрожує найбільше. Не боротися на кожному кроці проти жорстокого большевицького режиму значить приймати його за свій! Боротьбою проти сталінських колгоспів докажемо перед світом, що ми більше ніж хто не будь у світі ненавидемо большевицьку заразу!» $[18,258]$. У зверненні «Українські селяни!» зазначалося: «Боріться всередині колгоспів так же вперто і завзято, з такою єдністю і згуртованістю, як Ви боролися проти заведення колгоспів! Цією боротьбою Ви завдаватимете нових ударів по зненавидженій большевицькій тюрмі народів і наближатимете день іiі повного розвалу. ... Тільки в Українській державі український селянин житиме вільно, буде мати власну землю, сам працюватиме на ній і буде по своїй волі розпоряджатися плодами власної землі і своєї праці» [16, 307].

У підпіллі розробили також спеціальні інструкції у формі питальника для збору інформації про колгоспи й радгоспи, де виділялися їхні основні характеристики. При цьому така інформація систематизувалася як окремий розділ і додавалася до загального суспільно-політичного звіту [19, 55-55зв.].

Націоналісти ретельно фіксували процес колективізації у жовтні 1948 р., коли шантажем і терором населення змушували вступати в колгоспи. Саме тому пропагандистський апарат, власне, як $\mathrm{i}$ всі кадри, мали вести роз'яснювальні гутірки з населенням, даючи практичні вказівки поведінки в час насильного втягування до колгоспів та підтримування їх у дусі боротьби. Всі техзвена Карпатського краю мали випустити достатню кількість антиколгоспних листівок, закликів і карикатур, а також подбати, щоб ці матеріали безперебійно з'являлися у цілому терені, зокрема, посилено там, де більшовики намагалися зорганізувати нові колгоспи. У зв'язку із цим рекомендувалося передруковувати протиколгоспні листівки, заклики, карикатури для забезпечення цією літературою всіх населених пунктів і підпільних груп з метою використання й поширення $[5,308]$.

У боротьбі проти колективізації підпільники використовували не тільки пропаганду, але й конкретні бойові акції щодо осіб, які втілювали, реалізовували політику влади. Щоправда, цьому передували неодноразові попередження: «Організаторам, членам ініціативних груп і правлінь колгоспів!... Ви добре знаєте, що сталінські колгоспи - це грізне голодування колгоспників, а 
вкінці їх голодова смерть. ... Незважаючи на те все, Ви вислоговуєтеся сталінським собакам та намагаєтеся всякими насильницькими засобами затягнути селян в сталінські колгоспи. ... Якщо не покинете цю огидну вислужницьку працю на користь ворога, як не виступите з ініціативних груп чи з правлінь колгоспів, то народ буде вважати Вас за найгірших злочинців. А щодо злочинів супроти народу існує в цілому світі єдиний закон - знищувати їх всякими можливими способами» [23, 82]. Так, після неодноразових попереджень 19 липня 1945 р. у с. Дорохівці Заставнянського p-ну підпільники вбили фінагента того ж села Дмитра Вітчука і його дружину, у яких вилучили 2000 крб. [9, 70].

Провідник Карпатського крайового проводу ОУН Я. Мельник-«Роберт» (1.09.1946 р.) вважав, що спочатку потрібно дати зрозуміти членам ініціативної групи сутність їхньої антинародної діяльності. Якщо після дворазового попередження члени ініціативної групи продовжували попередню колективізаційну роботу, то дозволялося перейти до практики. Перший раз можна було покарати буками, але так, щоб особа відчула «тверду руку», а в крайніх випадках (агент) - вжити суворішіх заходів. Публічно дозволялося карати найбільш активних осіб. При цьому слід було вказувати на те, за що конкретно їх покарали, нагадувати про всі попередження [13, 142]. Про розгром колгоспу потрібно було попередити заздалегідь, а після цього - допомогти колгоспникам і не «випускати» ї із-під своєї опіки $[10,18]$. Спецоргани документували такі випадки. Так, у західних областях УРСР протягом 1947 р. ліквідували 29 голів і активістів колгоспів (1,3% від загальної кількості ліквідованих у повстанських акціях), а вже у 1948 р. - 339 (15,2 \%), 1949 р. 226 (18,8 \%), 1950 р. - 84 (20,6 \%), 1951 р. - 28 (21,7 \%), 1952 р. - 6 (17,1 \%) [29, 28]. Підпілля у Дрогобицькій області (1948 р.) провело 9 терористичних актів проти колгоспного активу, колгоспників і осіб, які подали заяви про вступ до колгоспу, в результаті яких вбили 4 голів колгоспів, 1 поранили і вбили 12 осіб, які подали заяви про вступ до колгоспу. Найбільша кількість терактів проти колгоспного активу відбулася у Славському, Меденицькому, Підбузькому, Дрогобицькому, Журавненському, Мостиському і Нижньо-Устрицького районах $[22,94]$. У першому кварталі 1949 р. підпілля здійснило 85 терактів проти партійно-радянського активу і 66 проти колгоспників. Про активізацію антиколгоспної боротьби свідчить і те, що у першому кварталі 1947 р. було здійснено 189 збройних проявів, а в першому кварталі 1949 р. - 299 [11, 286]. За цей же період підпільники вбили 100 голів колгоспів і 178 колгоспників [17, 9]. Зазначимо, що застосовувати колективну відповідальність суворо заборонялося, хоча в окремих випадках - у силу різних обставин - вона мала місце.

Зі свого боку, спецоргани розробили заходи з метою попередження терактів проти голів колгоспів і колгоспного активу. У селах, де найпотужніше діяв національно-визвольний рух, широко практикували виставлення біля будинків, особливо на околицях, підлісних місць, добре замаскованих засідок, секретів, власне, як силами чекістсько-військових груп, так і силами бійців ВБ і ГОГП. Широко залучався перевірений колгоспний актив для несення служби охорони з огородження колгоспів, колгоспників і їх майна від нападів. Для цього цей актив озброїли, провели насадження у селах відданої і працездатної агентури $[22,96]$.

За підрахунками М. Сеньківа, впродовж 1946 р. у західних областях УРСР націоналісти здійснили 2598 антиколгоспних акцій, а в січні-жовтні 1947 р. - 1320 [32, 166]. Від січня до грудня 1948 р. у західних областях УРСР відбулося 96 нападів на колгоспи. Вони супроводжувалися підпалами колгоспних будівель, знищенням колгоспного майна. Таких заходів проведено 12 у Дрогобицькій області, 15 у Волинській, 25 у Львівській, 13 у Рівненській, 10 у Станіславській, 21 у Тернопільській $[17,9]$. За час від 1 жовтня до 31 грудня 1947 р. на території західних областей УРСР відзначено 15 випадків підпалів колгоспного майна, а за час від 1 січня до 17 березня 1948 р. - 18. Таким чином, упродовж 1 жовтня 1947 р. - 17 березня 1948 р. відбулося 33 випадки підпалу підпільниками колгоспного майна; з них - у Львівській 12 (від 1 жовтня до 17 березня 1948 р.), 8 (від 1 жовтня до 31 грудня 1947 р.), 4 (від 1 січня до 17 березня 1948 р.); у Тернопільській 7/2/5; у Івано-Франківській 7/4/3; у Дрогобицькій 5/1/4; у Рівненській 2/0/2) [14, 196$]$.

Окремі доповідні містили зіставлення між наявністю колгоспів і кількістю здійснених збройних проявів. Так, у районах Дрогобицької області станом на 1 листопада 1949 р. було 799 колгоспів, щодо яких здійснено 174 збройні прояви [3, 107]. 18 вересня 1946 р. о 24.00 групою кущового 
провідника «Сойки» було здійснено напад на колгосп ім. Леніна у с. Уріж Підбузького р-ну. Підпільники, підійшовши до охорони колгоспу, яка складалася із 7 бійців ВБ на чолі з дільничним уповноваженим Коземирко, відкрили по ній автоматно-кулеметний вогонь. У перестрілці загинув боєць ВБ Йосиф Бесараб і поранений Іван Бесараб. У ході перестрілки згоріли 2 конюшні, сарай, електромотор, 18 тон сіна, 41 тонна соломи, 18 тонн зерна, 3 тонни ячменю, 3 тонни вівса, 1 тонна жита і пшениці $[7,88 ; 8,95] .9$ лютого 1948 р. у с. П'ядики Коломийського району підпільниками спалено 33 тонни соломи і 17 тон м'якини, що належали Коломийському радгоспу [14, 200].

Характеризуючи настрої учасників націоналістичного підпілля у зв'язку із колективізацією сільського господарства у західних областях УРСР, органи МДБ на основі захоплених оунівських документів, а також із отриманих від підпільників і їхніх симпатиків показів зазначали: розгортання колгоспного будівництва викликало серйозне розгублення й деморалізацію серед оунівського підпілля. 15 листопада 1948 р. у с. Михайлевичі Дрогобицької області підпільник Хомич у розмові з інформатором заявив: «...Справи нашої групи у зв'язку із проведенням колективізації у селах дуже погані, нема надійних людей, у яких можна було би переховуватися і проводити свою роботу. Багато перейшли на сторону совітів, а багато втратили віру у підпільників. I тепер, у зв'язку із проведеною колективізацією, підпільники не заходять в ці села, а переховуються у лісах і не групами, як це було ще весною, а по-одинці, саме більше по дві особи» $[17,1]$.

Таким чином, у боротьбі проти визвольного руху у Карпатському краї ОУН радянське керівництво покладало великі надії на суцільну колективізацію села, яка розгорнулася у 1948 - 1949 рр. Історик Михайло Сеньків аргументовано виділяє три етапи процесу колективізації західноукраїнських земель. Перший припадає на роки становлення радянської влади (1940 - перша половина 1941 рр.) та її відновлення (1944 - 1946 рр.), коли виникали окремі колгоспи. На другому етапі (1947 - 1948 рр.) розпочалася суцільна колективізація та масове відчуження селянина від власності, розгортались жорстокий терор проти національно-визвольного руху та депортаційно-переселенські акції. На третьому етапі (1949 - 1952 рр.) завершено суцільну колективізацію, утверджено колгоспний лад, а селянина перетворено на новітнього кріпака, підірвано соціально-економічну базу національно-визвольного руху $[34,465]$. Колективізація здійснювалася за суттєвої допомоги приїжджих кадрів. Так, упродовж 1944 - 1950 рр. до західних областей УРСР прибули 19000 агрономів, зоотехніків, інженерів, землеупорядників та інших працівників сільськогосподарського виробництва; з них близько 40 \% повернулися на батьківщину $[32,179]$. Прагнучи здійснити швидку колективізацію західноукраїнського селянства, радянська влада почала застосовувати репресії, використовуючи грубі насильницькі методи, одним з яких була загроза депортації. Група радянського партійного активу, керована Дорофеєвим, прибула у березні 1948 р. у с. Топорівці Городенківського р-ну. Вона не проводила будь-яких заходів щодо створення колгоспу, не було організовано зборів колгоспників. Натомість група розпочала роботу зі збору посівного матеріалу і усуспільнення сільгоспінвентаря та робочої худоби. При цьому посівний матеріал і сільгоспінвентар відбирали не тільки у тих мешканців, які подали заяви про вступ до колгоспу, але й у всіх без винятку. Під час збору посівного матеріалу група партійного активу проводила масовий обшук у господарствах селян. Забирали сало, масло, жіночі хустки, речі й гроші. Ті ж, хто опирався незаконному обшуку, зазнавали побиття партійним активом $[14,325]$. Усі ці незаконні заходи партійного активу тривали від 16 до 19 березня й викликали обурення у населення. Як наслідок, вранці 19 березня 1949 р. біля сільради у с. Топорівці зібралися близько 300 жінок, які не випускали радянський партійний актив із сільради, вимагаючи викликати у село районних керівників. На цю вимогу були викликані начальники РВ МВС і РВ МДБ. Люди, які зібралися біля сільради, висловили скарги на незаконні дії групи. Проведене розслідування підтвердило об'єктивність скарг громадян [14, 326].

Вагомим аргументом у процесі виконання завдання колективізації стала податкова система. Під її непосильним тягарем селяни нерідко змушені були вступати до колгоспів. Отже, 1948 1949 pp. - це час масової колективізації у Карпатському краї ОУН, яка водночас була однією 3 форм боротьби проти визвольного руху. Основною соціальною базою ОУН і УПА були селяни, які брали не лише активну участь у боротьбі проти радянської влади, але й виконували інші допоміжні функції для забезпечення діяльності підпілля (продуктами, одягом, розвідувальними мате- 
ріалами тощо). Антиколгоспний рух у Карпатському краї ОУН, підтримуваний підпіллям, набрав великих масштабів.

Пропагандистська робота націоналістів давала свої результати. Селяни відмовлялись сплачувати податки, продавати хліб державі за низькими цінами. Вони знищували або й продавали реманент, худобу, не виходили на роботу, втікали до міст, ховалися у лісах. Так, чекісти констатували: план хлібопоставок по Дрогобицькій області станом на 15 листопада 1944 р. було виконано на 93,8 \% [21, 18]. У Станіславській області (1950) з 246000 працездатних колгоспників 46000 (18 \%) не виробили мінімум трудоднів без поважних причин [32, 155]. Селяни чинили послідовний опір колективізації, внаслідок чого каральна система розгорнула репресії проти них. Їхні масштаби набрали загрозливих обертів. Тому радянська система змушена була реагувати. За порушення у цій сфері 19 серпня 1946 р. у Львівській області виключили з партії 84 комуністів, у Дрогобицькій - 150, Тернопільській - 150, Рівненській - 20 [32, 143]. Власне, не тільки широкі маси селянства чинили опір колективізації, але й окремі члени партії. 17 березня 1946 р. питання колективізації обговорювалося на загальних зборах сільської партійної організації у с. Копашне Хустського округу Закарпатської області, на яких більшість комуністів висловилися за організацію колгоспу. Однак окремі члени парторганізації виступили проти колективної форми ведення сільського господарства, ба навіть більше - почали з цього приводу вести антиколгоспну агітацію. При цьому член партії Гангур у виступах на загальних зборах заявив: «...Колгоспу організовувати не потрібно, так як нас комуністів будуть звинувачувати у знущаннях над народом» $[20,176]$. У результаті антиколгоспних виступів з боку окремих членів парторганізації у с. Копашне відзначалася ативізація антирадянської діяльності [20, 175, 177].

Колективізація, попри тиск, не відбувалася бажаними для влади темпами. Станом на 10 червня 1947 р. у Дрогобицькій області відновлено й реорганізовано 20 колгоспів (із наявних 275 колгоспів у 1940 - 1941 pp.): у 1945 р. 7 відновлено, 2 організовано, відповідно у 1946 р. - 4/2, у 1947 р. 2/3 [4, 25-26]. Ще гіршою ситуація була наприкінці 1946 р. в Івано-Франківській області, де діяло лише 18 колгоспів (608 господарств) із 274 довоєнних (19 807 господарств) [1, 128].

Попри те, з переходом до суцільної колективізації до кінця 1948 р., у Волинській області було колективізовано 80 \% селянських господарств, у Дрогобицькій - $79 \%$, у Чернівецькій - $77 \%$, у Львівській - 34 \%, у Тернопільській - $34 \%$, у Рівненській - $25 \%$, у Станіславській - $17 \%$, у Закарпатській - 46 \% [32, 127-128]. Станом на 1 травня 1949 р. у західних областях УРСР було організовано 5304 колгоспів, які об’єднували 781600 (54,2%) загальної кількості селянських господарств. Об'єднано у колективні господарства 2201800 га (67,6 \% всієї орної землі) [11, 284]. На 1 січня 1950 р. у Чернівецькій області об’єднані в колгоспи 94,5 \% всіх господарств і 98 \% всієї землі $[6,166]$. Станом на 1 грудня 1950 р. в Івано-Франківській області колективізовано 96,9 \% селянських господарств і усуспільнено 99,1 \% земельної площі передгірської і низинної зони $[24,13]$.

Загалом створення колгоспів упродовж 1944 - 1950 рр. відбувалося такими темпами. Всього створили та відновили 6703 колгоспів (1944 р. - 38, 1945 р. - 69, 1946 р. - 147, 1947 р. - 1118, 1948 р. - 3293, 1949 р. - 1382, 1950 р. - 656). 3 них у Волинській області - 1075 (1944 p. - 0, 1945 p. - 13, 1946 p. - 2, 1947 p. - 260, 1948 p. - 734, 1949 p. - 66, 1950 p. - 0), у Дрогобицькій 810 (1944 p. - 0, 1945 p. - 11, 1946 p. - 5, 1947 p. - 49, 1948 p. - 704, 1949 p. - 36, 1950 p. - 5), у Закарпатській - 538 (1944 p. - 0, 1945 p. - 0, 1946 p. - 2, 1947 p. - 11, 1948 p. - 398, 1949 p. - 121, 1950 р. - 6), у Львівській - 933 (1944 p. - 1, 1945 p. - 10, 1946 p. - 34, 1947 p. - 171, 1948 p. - 308, 1949 p. - 162, 1950 p. - 247), у Рівненській - 1028 (1944 p. - 1, 1945 p. - 10, 1946 p. - 8, 1947 p. 141, 1948 р. - 459, 1949 р. - 332, 1950 р. - 77), у Івано-Франківській - 646 (1944 р. - 0, 1945 р. - 1, 1946 p. - 20, 1947 p. - 53, 1948 p. - 160, 1949 р. - 252, 1950 р. - 160), у Тернопільській - 1182 (1944 p. - 35, 1945 p. - 8, 1946 p. - 29, 1947 p. - 193, 1948 p. - 364, 1949 p. - 397, 1950 p. - 156), у Чернівецькій - 491 (1944 р. - 1, 1945 р. - 16, 1946 р. - 47, 1947 р. - 240, 1948 р. - 166, 1949 p. - 16, 1950 p. - 5) [32, 280; 36, 3].

Висновки. Отже, репресивні форми й методи проведення колективізації у західних областях УРСР загалом і у Карпатському краї ОУН зокрема, наштовхнулися на масштабний опір українського визвольного руху та селянства. Водночас радянська адміністрація розглядала колективіза- 
цію одним із засобів боротьби проти ОУН і УПА. Адже через примусовий вступ селян до колгоспів націоналісти позбавлялися економічної та людської бази. Однак діяльність визвольного руху перешкоджала швидкій колективізації села, яку вдалося завершити тільки на початку 1950-х рр.

\section{СПИСОК ВИКОРИСТАНИХ ДЖЕРЕЛ І ЛІТЕРАТУРИ}

1. Андрухів І. Боротьба радянської влади проти збройних формувань ОУН та УПА на теренах Станіславської (Івано-Франківської) області в 40 - 50-х рр. XX ст. / І. О. Андрухів, І. Я. Любінець // Інтелігенція і влада. Громадсько-політичний і науковий збірник. - Одеса, 2008. - № 11. - С. 119-133.

2. Галузевий державний архів Служби безпеки України (далі ГДА СБУ). - Ф. 2-Н. - Оп. 57 (1953). Спр. 1. - Т. 1.

3. ГДА СБУ. - Ф. 2-Н. - Оп. 60 (1953). - Спр. 2. - Т. 5.

4. ГДА СБУ. - Ф. 2-Н. - Оп. 90 (1951). - Спр. 33.

5. ГДА СБУ. - Ф. 2-Н. - Оп. 106 (1954). - Спр. 2.

6. ГДА СБУ. - Ф. 2-Н. - Оп. 110 (1954). - Спр. 2. - Т. 7.

7. ГДА СБУ. - Ф. 2-Н. - Оп. 32 (1960). - Спр. 5.

8. ГДА СБУ. - Ф. 2-Н. - Оп. 32 (1960). - Спр. 6.

9. ГДА СБУ. - Ф. 2-Н. - Оп. 34 (1960). - Спр. 2.

10. ГДА СБУ. - Ф. 2-Н. - Оп. 93 (1954). - Спр. 1.

11. ГДА СБУ. - Ф. 2-Н. - Оп. 99 (1954). - Спр. 8. - Т. 5.

12. ГДА СБУ. - Ф. 2-Н. - Оп. 99 (1954). - Спр. 8. - Т. 6.

13. ГДА СБУ. - Ф. 13. - Спр. 372. - Т. 18.

14. ГДА СБУ. - Ф. 13. - Спр. 372. - Т. 49.

15. ГДА СБУ. - Ф. 13. - Спр. 372. - Т. 50.

16. ГДА СБУ. - Ф. 13. - Спр. 372. - Т. 51.

17. ГДА СБУ. - Ф. 13. - Спр. 372. - Т. 95.

18. ГДА СБУ. - Ф. 13. - Спр. 376. - Т. 10.

19. ГДА СБУ. - Ф. 13. - Спр. 376. - Т. 28.

20. ГДА СБУ. - Ф. 16. - Оп. 7. - Спр. 4. - Т. 10.

21. ГДА СБУ. - Ф. 71. - Оп. 6. - Спр. 29.

22. ГДА СБУ. - Ф. 71. - Оп. 6. - Спр. 176.

23. ГДА СБУ. - Ф. 71. - Оп. 6. - Спр. 184.

24. Державний архів Івано-Франківської області (далі ДАІФО). - Ф. 1-П. - Оп. 1. - Спр. 1154.

25. Історія українського селянства: Нариси в 2 т. / [ред. Володимир Литвин]. - Київ: Наукова думка, 2006. - T. 2. -653 c.

26. Кентій А. Нарис боротьби ОУН-УПА в Україні (1946-1956 pр.) / Анатолій Кентій. - Київ: Інститут історії України НАН України, 1999. - 111 с.

27. Киричук Ю. Український національний рух 40-50-х років XX століття: ідеологія та практика / Юрій Киричук. - Львів: Добра справа, 2003. - 464 с.

28. Ленартович О. Селянство Захудної України у національно-визвольній боротьбі 1944 - 1950 pp. / О. Ленартович. - Луцьк, 1998. - 350 с.

29. Мороз В. Зиновій Тершаковець-«Федір». - Літопис УПА. Серія «Події і люди» / Володимир Мороз. - Торонто-Львів: Видавництво «Літопис УПА», 2011. - 128 с.

30. Мороз О. Українське селянство першої половини XX ст. / О. Мороз, С. Злупко. - Львів, 1999. - 268 с.

31. Організація Українських Націоналістів і Українська Повстанська Армія. Історичні нариси. - Київ: Інститут історії України НАН України, 2005. - 496 с.

32. Сеньків М. Західноукраїнське село: насильницька колективізація 40 - поч. 50-х pp. XX ст. / Михайло Сеньків. - Львів: Інститут українознавства ім. І. Крип'якевича, 2002. - 292 с.

33. Сеньків М. Форми і методи відчуження селянства від власності у західному регіоні України (друга половина 40-х - початок 50-х рр. ХХ ст.) / Михайло Сеньків // Дрогобицький краєзнавчий збірник [ред. кол. Леонід Тимошенко (гол. ред.), Любомир Винар, Леонід Зашкільняк, Ярослав Ісаєвич та ін.]. - Дрогобич: Коло, 2003. - Вип. VII. - С. 465-473.

34. Сеньків М. Форми і методи відчуження селянства від власності у західному регіоні України (друга половина 40-х - початок 50-х рр. ХХ ст.) / Михайло Сеньків // Дрогобицький краєзнавчий збірник [ред. кол. Леонід Тимошенко (гол. ред.), Любомир Винар, Леонід Зашкільняк, Ярослав Ісаєвич та ін.]. - Дрогобич: Коло, 2003. - Вип. VII. - С. 465-473.

35. Центральний державний архів громадських об’єднань України (далі ЦДАГОУ).- Ф. 1. - Оп. 23. Спр. 2968. 
36. ЦДАГОУ. - Ф. 1. - Оп. 30. - Спр. 2162.

\section{REFERENSES}

1. Andrukhiv I. Borotba radianskoi vlady proty zbroinykh formuvan OUN ta UPA na terenakh Stanislavskoi (Ivano-Frankivskoi) oblasti v 40 - 50-kh rr. KhKh st. / I. O. Andrukhiv, I. Ya. Liubinets // Intelihentsiia i vlada. Hromadsko-politychnyi i naukovyi zbirnyk. - Odesa, 2008. - № 11. - S. 119-133.

2. Haluzevyi derzhavnyi arkhiv Sluzhby bezpeky Ukrainy (dali HDA SBU). - F. 2-N. - Op. 57 (1953). Spr. 1. - T. 1 .

3. HDA SBU. - F. 2-N. - Op. 60 (1953). - Spr. 2. - T. 5.

4. HDA SBU. - F. 2-N. - Op. 90 (1951). - Spr. 33.

5. HDA SBU. - F. 2-N. - Op. 106 (1954). - Spr. 2.

6. HDA SBU. - F. 2-N. - Op. 110 (1954). - Spr. 2. - T. 7.

7. HDA SBU. - F. 2-N. - Op. 32 (1960). - Spr. 5.

8. HDA SBU. - F. 2-N. - Op. 32 (1960). - Spr. 6.

9. HDA SBU. - F. 2-N. - Op. 34 (1960). - Spr. 2.

10. HDA SBU. - F. 2-N. - Op. 93 (1954). - Spr. 1.

11. HDA SBU. - F. 2-N. - Op. 99 (1954). - Spr. 8. - T. 5.

12. HDA SBU. - F. 2-N. - Op. 99 (1954). - Spr. 8. - T. 6.

13. HDA SBU. - F. 13. - Spr. 372. - T. 18.

14. HDA SBU. - F. 13. - Spr. 372. - T. 49.

15. HDA SBU. - F. 13. - Spr. 372. - T. 50.

16. HDA SBU. - F. 13. - Spr. 372. - T. 51.

17. HDA SBU. - F. 13. - Spr. 372. - T. 95.

18. HDA SBU. - F. 13. - Spr. 376. - T. 10.

19. HDA SBU. - F. 13. - Spr. 376. - T. 28.

20. HDA SBU. - F. 16. - Op. 7. - Spr. 4. - T. 10.

21. HDA SBU. - F. 71. - Op. 6. - Spr. 29.

22. HDA SBU. - F. 71. - Op. 6. - Spr. 176.

23. HDA SBU. - F. 71. - Op. 6. - Spr. 184.

24. Derzhavnyi arkhiv Ivano-Frankivskoi oblasti (dali DAIFO). - F. 1-P. - Op. 1. - Spr. 1154.

25. Istoriia ukrainskoho selianstva: Narysy v 2 t. / [red. Volodymyr Lytvyn]. - Kyiv: Naukova dumka, 2006. T. $2 .-653 \mathrm{~s}$.

26. Kentii A. Narys borotby OUN-UPA v Ukraini (1946-1956 rr.) / Anatolii Kentii. - Kyiv: Instytut istorii Ukrainy NAN Ukrainy, 1999. - 111 s.

27. Kyrychuk Yu. Ukrainskyi natsionalnyi rukh 40-50-kh rokiv XX stolittia: ideolo $\neg$ hiia ta praktyka / Yurii Kyrychuk. - Lviv: Dobra sprava, 2003. - 464 s.

28. Lenartovych O. Selianstvo Zakhudnoi Ukrainy u natsionalno-vyzvolnii borotbi 1944 - 1950 rr. / O. Lenartovych. - Lutsk, 1998. - 350 s.

29. Moroz V. Zynovii Tershakovets-«Fedir». - Litopys UPA. Seriia «Podii i liudy» / Volodymyr Moroz. Toronto-Lviv: Vydavnytstvo «Litopys UPA», 2011. - $128 \mathrm{~s}$.

30. Moroz O. Ukrainske selianstvo pershoi polovyny KhKh st. / O. Moroz, S. Zlupko. - Lviv, 1999. - 268 s.

31. Orhanizatsiia Ukrainskykh Natsionalistiv i Ukrainska Povstanska Armiia. Istorychni narysy. - Kyiv: Instytut istorii Ukrainy NAN Ukrainy, 2005. - $496 \mathrm{~s}$.

32. Senkiv M. Zakhidnoukrainske selo: nasylnytska kolektyvizatsiia 40 - poch. 50-kh rr. XX st. / Mykhailo Senkiv. - Lviv: Instytut ukrainoznavstva im. I. Krypiakevycha, 2002. - 292 s.

33. Senkiv M. Formy i metody vidchuzhennia selianstva vid vlasnosti u zakhidnomu rehioni Ukrainy (druha polovyna 40-kh - pochatok 50-kh rr. XKh st.) / Mykhailo Senkiv // Drohobytskyi kraieznavchyi zbirnyk [red. kol. Leonid Tymoshenko (hol. red.), Liubomyr Vynar, Leonid Zashkilniak, Yaroslav Isaievych ta in.]. - Drohobych: Kolo, 2003. - Vyp. VII. - S. 465-473.

34. Senkiv M. Formy i metody vidchuzhennia selianstva vid vlasnosti u zakhidnomu rehioni Ukrainy (druha polovyna 40-kh - pochatok 50-kh rr. XX st.) / Mykhailo Senkiv // Drohobytskyi kraieznavchyi zbirnyk [red. kol. Leonid Tymoshenko (hol. red.), Liubomyr Vynar, Leonid Zashkilniak, Yaroslav Isaievych ta in.]. - Drohobych: Kolo, 2003. - Vyp. VII. - S. 465-473.

35. Tsentralnyi derzhavnyi arkhiv hromadskykh obiednan Ukrainy (dali TsDAHOU). - F. 1. - Op. 23. Spr. 2968.

36. TsDAHOU. - F. 1. - Op. 30. - Spr. 2162.

Стаття надійшла до редакиії 28.09.2017 p. 